\title{
From Gender Identity Oppression to Power Reversal in the Novel Calabai
}

\author{
I Gusti Ayu Agung Mas Triadnyani \\ Universitas Udayana, Indonesia \\ E-mail: mtriadnyani@gmail.com
}

\begin{abstract}
Recently, the sociocultural problems of transgender have shown an increase. The novel, Calabai, vividly depicts various acts of violence perpetrated by Bugis tribesmen against transgender members of the community. They consider transgender as deviant or different. From a humanist perspective, this view forms a violation of the principles of human rights. Actually, this novel develops the idea of cultural identity. Through deconstructive analysis according to Derrida, this study exposes the ideology embedded within such a textual representation of transgender. It reaches two conclusions. First, a reversal of ideology takes place in the text; from oppression based on discrimination, to a power reversal. Second, being regarded as a human being and receiving respect from another human being become a form of recognition of personal and cultural identity.
\end{abstract}

Keywords: deconstruction; Derrida; difference; humanity; violence; transgender

\section{INTRODUCTION}

Indonesia is an independent and sovereign country. By the Constitution of 1945, the state has guaranteed the rights of every citizen, including the freedom to practice religion, and freedom from discrimination. Nevertheless, coercions towards individuals or groups that form the minority still occur in Indonesia's modern history at the hands of the majority. In 2016, Komnas HAM (the National Board of Human Rights Affairs) received a number of complaints against violations of human rights. These occurred throughout Indonesia, including West Java, Aceh, Jakarta, Belitung, and North Sulawesi. In a number of different areas, groups of people committed acts of violence against other groups, simply on the basis of differences of ethnicity, religion, and race (http://informasidalamnegeri. blogspot.co.id/2016/07/11-kasus-pelanggaran-hakkebebasan.html).

Despite the stipulation of human rights in Indonesia, problems still arise due to cultural differences. The Indonesian government faces challenges in overcoming these problems, especially human rights abuses. Not only the government, but society in general are responsible for upholding the value of human rights. The need to uphold human rights principles is relevant across all cultural contexts and minority groups.

One of the most frequent human rights violations in Indonesia takes the form of discrimination against the transgender community as a minority group. Research demonstrates that they experience verbal assault, violence, oppression, and excommunication from the community. Hamid (2011) conducted research about transgenders in Malang, East Java, especially in relation to their experience of domestic violence. Yuliani (2012) also highlighted the experience of transgender individuals facing discrimination in accessing public services in Indonesia. Research by Faidah (2013) found that transgender individuals in Surabaya experience a multiple identity as deviants and yet they accept this condition as their destiny from God. Globally, Dede Oetomo (2001) described their struggles around the world. This book opened 
up new ideas about the impact of discrimination upon transgender.

Discrimination against the transgender community has not escaped the attention of literary writers in Indonesia. Several writers express the idea of this phenomenon in their literature. These include the novels: Pasung Jiwa (The Trapped Soul) by Okky Madasari, Deleilah Tak Ingin Pulang dari Pesta (Deleilah Doesn't Want to Come Home from the Party) by Phutut E.A., and a collection of short stories, Bastian dan Jamur Ajaib (Bastian and the Magic Mushroom) by Ratih Kumala.

Another literary work that addresses the issue of transgender in Indonesia is the novel Calabai (2016), written by Pepi Al-Bayqunie, his real name is Saprillah. He also wrote several other novels, such as Tahajud Sang Aktivis (Tahajud the Activist) (2012), Kasidah Maribeth (2013), and Jejak (Footsteps) (2015). The novel Calabai exposes the issues of the transgender community, namely the bissu in Bugis society in South Sulawesi, and their experience of various acts of violence as well as their important position in society. The Bissu community is one of the communities that still conducts and preserves the ancient Bugis culture. Living in Pangkep, South Sulawesi, Bissu were formerly known as the ancient Bugis priests prior to the arrival of Islam. Those priests had physically male characteristics, but their attitudes and behaviors were that of women (transvestites or calabai in Bugis term). In addition, as bissu, they had their own certain spiritual powers. Their magical power could clearly be seen when performing maggirik activity (piercing the body with sharp tools). They mastered the torilangi language (language of the sky), so as to communicate with the ancestors. They also had the ability to predict and perform medical treatments as shamans (Makkulau, 2008)

This novel is worthy of critical analysis as it deals with the important human rights issue of discrimination against a minority group. Moreover, when approaching the violation of human rights, it also alludes to its cultural context, namely the Bugis culture.

The issues of human rights are closely linked to the notions of humanism. According to Ubaidullah (2012) humanism generally relates to the various views related to human existence and the various problems they face as members of a society. The concept of humanism can be viewed from a number of perspectives such as religion, psychology, sociology, and culture. Humanism in the realm of religion, for example, emphasizes the virtues of human conscience and how people obey religious teachings conducted through the scriptures. Meanwhile, secular humanism, as opposed to religious humanism, reflects the rise of technology and especially globalization. This viewpoint believes that one's dignity is acquired through logic, and they even assume religion and local tradition cannot be limiting. In psychology, humanism emphasizes the development of the human personality. Therefore, there are various viewpoints to humanism for the sake of knowledge.

Etymologically, humanism is an exaltation of human characteristics. In other words, the human is the center of everything (anthropocentricism). Humans strive to reestablish themselves to become independent and dignified. This angle actually drives people to gain the opportunity of developing the human intuitive sense.

Humanism values are particularly evident in literary works. They draw pictures of human life, in terms of human's relations to God, to others, and to the natural environment. Through literature, various ways of human thoughts, activities and speeches are illustrated. These cover many aspects such as the political, economic, social, and cultural. The novel Calabai, chosen as the object of this study exposes the phenomenon of Bissu community within the Bugis tradition as they experience a range of acts of oppression deemed to violate their human rights.

Given the complexity of the gender of the bissu and their social roles, the issue of self-identity becomes highly relevant. Determining a person's identity, particularly whether male or female, can become a major issue. Most societies hold the conviction that in this world there are only two choices of sex, i.e. male and female. In this regard, when a person expresses a dual gender identity, conflict can arise. According to the majority interpretation of the holy scriptures of Islam, the dominant religion of Indonesia and Bugis society, a person is strongly banned from expressing an attitude that is deemed to be "unnatural" in particular, a man who behaves like a woman, or likewise, a woman who behaves like a man (http://www.republika.co.id/berita/koran/ dialog-jumat/16/02/26/0357g813). In addition to the violation of gender norms, Rudi (2016) also explains that homosexuality is regarded as another social deviation in Indonesia. Most bissu, however, are not homosexual.

The sensitive issue of deviation from gender norms in Indonesia requires careful consideration. The 
novel Calabai delivers a story of the Bissu community and their experience of a series of violent acts through the lens of the main character Saidi. According to the author, the novel is largely based on the real facts. Here, the main character of Saidi was bullied since childhood, not only by his friends, but especially by his father as well. The father was very disappointed with Saidi who presented as 'womanish.' He hoped his son would grow up to be a strong, tough, 'true-souled' man. Every day the father forced Saidi to work hard in the field. Saidi was also forced to quit school because he could not bear the torment from his fellow students. People around him in the community also often looked down on him. Even the mosque's preachers spoke ill of the calabai in general and constructed them as an example of deviance in the eyes of Islam (p.8).

While exposing social discrimination, it is also important to examine the ideology behind the text as the ideological underpinnings can influence the way subjects are portrayed, and with it bring powerful social consequences. According to Eagleton (1991: 1), there are some definitions of ideology. One of them is the process of production of meanings, signs, and values in social life.

This study adopts a poststructuralist theoretical paradigm to approach this text, in which the text becomes the focus of analysis, rather than surrounding social structures. To dismantle the text's meaning, this study engages Derrida's concept of deconstruction as a form of literary criticism. Through deconstruction, a text's ideology and meaning can be uncovered by a comparative analysis the applied words or terms. According to Derrida's notion, language is not about the unity of the signifier and signified, but the application of a series of signifiers. According to him, language is non-referential, which means it does not refer to the world or concept but to the signifiers (Haryatmoko, 2017).

Generally, each text carries a certain ideology. Deconstruction helps to uncover the ideology that is hidden within language. "Deconstruction tries to melt the ideology that is already frozen in the language. Actually, language is not a neutral means of communication, but liquid. Through language, certain ideology has programmed our way of thinking unconsciously" (Haryatmoko, 2015: 94). There are four steps to undertake deconstruction. First, determining the center of a text and its concept, including the point(s) of tension. Second, dismantling the text's ideology (usually through its binary logic). Three, reversing the metaphysical hierarchy and neutralizing it. Finally, disseminating or spreading its meaning.

\section{FINDINGS AND DISCUSSION The Center of the Text's Tension}

Following the deconstruction method, the first step is to uncover the center of the text's tension. This step is important to identify the focal point of the text, and around which the text constructs its own meaning system, including its contradictions. Through this process, the ideology constructed by the author can be brought to the surface. In the novel Calabai, the center of text is the oppression experienced by Saidi. In this case, readers are encouraged to express empathy towards Saidi and the community who suffered from this oppression. Thus, an overall binary opposition initially becomes apparent in this text; that is, the oppression $><$ comfort. Saidi's experiences, ranging from his childhood to adulthood, include being tortured by his father, insulted by his schoolmates, scorned at mosques and by the community. These individual experiences trigger readers' empathy for Saidi. His suffering contradicts the privilege and comfort experienced by his oppressors in the surrounding community, who are considered normal (not deviant), such as his fierce father, his peers at school, and so on. The contrast of the two sides reflects conflict between accepted normative behavior and unacceptable deviance in the society.

Because Saidi was unable to overcome the resulting discrimination on the basis of his perceived deviance, he decides to leave his homeland and family. He travels to Mallawa, District of Maros with the hope that a new place will bring him a better life. Evidently, in the new place, he encounters oppression equal to that of his homeland. While Saidi is allowed to live in the home of a kindhearted grandmother, the surrounding community refused to accept him.

"Calabai tidak boleh ada di kampung ini!" teriak seseorang dengan garang.

"Ya, calabai dilaknat Tuhan!"

"Calabai pembawa sial!"

“Usir calabai dari kampung kita!” (h. 68).

("Calabai are not allowed in this village!"

Someone shouted fiercely.

"Yes, calabai are cursed by God!"

"Calabai are bad luck!"

"Drive the calabai away from our village!" (68))

The quotation above shows the same reaction 
from the community towards the transgender. That is, people everywhere are not able to accept the existence of transgender.

The representation of oppression is demonstrated through the representation of several events experienced by Saidi. First, Saidi was tortured by his father (p.13). Second, Saidi was ridiculed by his fellow students, causing him to quit school (p.23). Thirdly, Saidi was scorned by Islamic preachers (p.18). Fourth, Saidi was humiliated by the surrounding community (p.18). Fifth, Saidi was expelled by the community while living far away from home, because he was considered as a sign of unluckiness (p.68).

These contrasting representations of a vulnerable Saidi against his privileged, comfortable oppressors lead the readers to express empathy for Saidi, and adopt a critical stance against the oppressors. This is what is commonly called the readers' point of view or stand point.

Saidi's experience of unpleasant events also provoke the readers' curiosity and interest: "He grows in two worlds: the body of a man, the soul of a woman. Like living at the gate between man and woman. Calabai, so typical the citizen greets him. The greeting exposes an orchestra which hurts his father's heart whenever it is delivered. Saidi has never been hurt or angry or offended by being labelled as a calabai " (p.11). The readers would take the side with Saidi because of the agonizing anguish that came to him. Saidi's suffering is placed on the highest metaphysical hierarchy. According to Haryatmoko (2015), the metaphysical hierarchy is inherent in the language (binary opposition).

The original umbrella binary opposition of oppression $><$ comfort also gives way to other smaller categories of oppositions. These include: normal $><$ deviant; male $><$ female; homo $>$ $<$ lesbi; body $><$ soul; violent father $><$ tender mother; sorrowful $><$ happy; Bissu community $><$ ordinary society; senior bissu $><$ junior bissu; bissu leader $><$ bissu member; religious $><$ irreligious. The above binary opposition contains a hierarchical position, that is normal higher than aberrant, soul is better than body, etc.

These oppositions above were subsequently reviewed and organized according to the dynamics of the original umbrella binary of oppression $><$ comfort. This results in the identification of four oppositions which support the main theme above. These were: normal $><$ deviant, body $><$ soul, bissu community $><$ ordinary society, and bissu leader $><$ bissu member.

The next storyline/plot of this novel depicts the tough struggles experienced by the character Saidi in the search for his life's destiny, namely to become the bissu leader. This kind of struggle is different with the oppression he endured in the earlier parts of the story. The theme of oppression is the way the author invites the reader's sympathy. The constructed truth by the text is that oppression will eventually gain its karma. Saidi was finally selected to be the leader of the great Bissu community. Saidi's suffering contrasts with the privilege and comfort of the people around him.

The binary logic of the original umbrella binary cannot be removed from the lower binary oppositions, such as normal $><$ deviate. These two pairs of binarities (normal $><$ deviate) contribute to the representation of the oppression of the main character. According to the prevailing social norms in society that have a male body but behave as women are identical with gender deviations, therefore people of this identity deserve to be oppressed and excommunicated. Views that discriminate against this group are still widely embraced by almost the majority of people in Indonesia (Denny J.A., 2014). Saidi suffered because he was considered abnormal (deviant), while people who were considered normal lived comfortably. The text even perpetuates the binary of Saidi's deviance through reference to the will of God. "Saidi's heart aches. Calabai are cursed by God ... " (p.68). In this novel, even God as the creator of nature and its contents, is portrayed as cursing the calabai.

The identification of the umbrella binary of oppression $><$ comfort, and its deconstruction into a set of smaller binary categories, suggests that the novel expresses the ideology about oppression.

\section{Contradictions of Text}

The next step in analysis involves searching for evidence of text contradictions. Saidi suffered both outward and inner pain. On the one hand, he questioned the fate that befell him. On the other hand, he struggled to survive as a transvestite, by following his own will. Finding it impossible to reconcile the 'soul of womanhood' within him with 
his physical appearance, the contrast between body and soul emerges; with the male body on one side, and her female soul on the other. Saidi was aware of the mismatch, and struggled to cope.

The following quotation describes Saidi's feelings. "Ia tidak tahu bagaimana cara menjadi lelaki. Bahkan ia sendiri tidak tahu lelaki itu apa dan mengapa wajib menjadi lelaki. Tonjolan jakun di leher, lingga di bawah perut, dan dada-yangtidak-bisa-berbuah terlalu sederhana untuk menjadi definisi lelaki baginya... Takdir meletakannya di dunia antara. Ia laksana hidup di perbatasan... (h. 22-23). (He does not know how to become a man. Even he himself does not know what is means to be a man and why it is mandatory to be a man. The bulging Adam's apple on the neck, the phallus underneath the stomach, and the chestthat-does-not-sprout-breasts are too simple to be the man's definition for him ... Destiny puts it in the intermediary world. He lives life on the border ... (pp. 22-23).

Julie Chou (2014) in a study revealed the presence of gene aberrations in the chromosomal formation system of carriers of male and female traits. Gene deviation is what is suspected as the main cause of a person who becomes a transvestite. In addition to genetic factors, environmental factors also play a major role in determining the occurrence of gender deviations. (http://www.kompasiana. com/juliechou/transgender-penyimpangan-genatau-perilaku). Dwijoseputro (1982) describes the same conclusion about the existence of this chromosome differences. Scientific research reinforces the assertion of destiny that must be accepted by transvestites. Thus, acts of violence in the form of humiliation, oppression, and exclusion of them must be stopped because their identity is actually natural. They have a double identity: both men and women.

The binary opposition between the body and the soul raises its own problems. Descartes, a famous philosopher through his ideas on the philosophy of body and soul, describes, among other things, a soulless body that will become a mechanically driven automaton. The bodiless soul, on the other hand, produces innate ideas without being enriched by the perception of the sensory complex. So the body and soul are reciprocal (Abidin, 2014).

In a philosophical and religious framework, the body tends to be seen as a vehicle of irrational desire and wild passion. This is something to be purified and controlled (Sugiharto, 2000). Thus, the binary opposition puts the soul in a more respectable position than the body which becomes secondary. In a religious framework, the body is seen as something negative because the body needs to be trained hard through discipline, meditation, and fasting. Triadnyani (2014) shows how a text (Calon Arang) is maintained over several ages for the purpose of disciplining the bodies of Shiva's followers in order to become individuals who are obedient to the teachings of Shiva. Likewise, being part of the bissu community is a way to devote the calabai's body to God so that the wild passions can be controlled. When the novel Calabai describes how a bissu gives his life to God, Puang Saidi asserts, "A bissu is not permitted to indulge his lust for man because bissu has dedicated his life to serve God and his fellow human beings" (p.279). Foucault (1977: 36) explains how bodies relate to power. The body can be a useful force only if the body is productive and obedient. This subjugation is obtained through violent and ideological instruments.

Starting from a single and unfettered view of body and soul dualism, the reader is directed to the next binary oppression, the bissu community in contrast to the common people. Saidi's meeting with Daeng Maddenring (adoptive parent) took him to Segeri Village. Segeri is heaven for calabai (p. 84). There calabai are respected. "The bissu are needed to fill the spiritual space ... (p.85). The bissu community in Segeri Village occupies a respectable position. This binary opposition reveals a metaphysical hierarchical reversal. If the main binary opposition between oppression versus comfort is accepted, the binary pair between the bissu community versus ordinary society can be regarded as a turning point. Saidi's suffering was somewhat anointed by the sharing of the experience of oppression by his adoptive parent overseas, Daeng Maddenring who was also a former bissu. He suffered more or less the same with Saidi. The aspects above support the ideology of the text, that is oppression

Being in the same community with him, Saidi felt comfortable, a kind of feeling of togetherness. At this point Saidi no longer regrets his transgendered 
state, but the oppressive treatment of the calabai by the people. In this point, Saidi moves away from the feelings of individual egoism, to the feeling of a shared destiny with a group based on shared experiences of oppression. The transfer of interest is not realized by the Saidi figure. Since childhood Saidi experienced great inner pressure that could not be expressed freely. Fortunately, his mother still acts as a protector and giver of affection. From the perspective of psychology, Saidi's transformation from the individual to group can be understood as an attempt to naturally deal with external pressures. By the time the individual has no more ability to bear it, that feeling is transferred to his group.

The novel reveals at this point that the stories of the oppression of the calabai in Segeri's country were longer and even more painful than that of Saidi. Based on the explanation from Puang Ma'rang, members of Darul Islam / Tentara Islam Indonesia forces attacked the bissu in 1960s. Leaders of the troops targeted the bissu community (p.30) and massacred them. Even in Bola Arajang (the center of the bissu community), Saidi also hears of an attack issued by a clerical group. "A few days ago there was a paccerama (lecturer) from Ujung Pandang. He said that the activity of the bissu is syirik should not be followed, as it destroys the aqidah, and therefore must be destroyed immediately, "(p. 91). Here is a quote about the incident of forcing by a group of people. "How painful they feel when they see Arajang's broken ball, some heirlooms are lost or burned. Not to mention the death of some bissu. They do not know what to do. And no power to hold back tears. The events made their hearts hard. Destruction of peers and the imposition of beliefs by the gorilla troops was heartbreaking "(p. 127).

In addition to the attack of the Islamic group, Kahar Muzakar, the bissu were also associated with the outlawed Indonesian Communist Party (PKI) in 1965-66. They were hunted down and customary activities are prohibited (p.128). The massacre left the bissu population drastically reduced. This situation was further complicated by the exclusion of the clergy. Usually if there is a traditional ceremony, the community invites bissu, but now they prefer to use shamans (p. 130). Income of bissu is increasingly difficult because there are rarely custom ceremonies, even customary land is also confiscated by the government. Formerly the customary land was a gift of King Segeri.

\section{The Reversal of Metaphysical Hierarchy}

The reversal of the metaphysical hierarchy between bissu communities and ordinary people also reveals the text ideology. On the one side this text exposes about the oppression experienced by Saidi, but the other side, it reveals the persistence of Saidi to reach the leader of Bissu. It shook the opposition of metaphysical hierarchy. The happiness that Saidi earned as part of the bissu community is illustrated in the following quotation. Saidi officially became a bissu ... "'Your wish is granted, my son ...' whispered Daeng Maddenring. Saidi nodded his head. He recalled his grim childhood (page. 220)." Such strong impulses and convictions had led Saidi into becoming a bissu. The oppression experienced during his childhood paid off by his position as a bissu is now respected by the surrounding community. "In Segeri, the bissu has raised Saidi's rank as a human ..." (p.324). Before becoming a bissu, Saidi was a transgender who often got insults, scoldings, and scorn. His pride was trampled. As a transvestite, he was not considered a human being. However, since he entered the bissu community, his level has increased.

Anderson (1972) explained some situations where one can occupy an honorable position in Indonesian society. One of them arises from joining a group that has power. Bissu is a spiritual group that connects farmers in Segeri Village with the highest strength of God. Through Sangiang Serri or the Goddess of Fertility, the bissu pray for fertility by casting a spell. They also perform a sacred dance called Maggirik (this dance is performed by piercing the kris into the body). With their spiritual strength, they easily gain a respectable position within the community of supporters of that tradition. The bissu are the interlocutors with the Supreme Being. In other words, the bissu occupy a highly honorable position, far beyond ordinary people.

Starting from Saidi's happiness, the reader is invited into the last opposition: bissu leader $><$ member of bissu. Before he was appointed bissu leader (Puang Matoa), he was a member of the bissu. As an ordinary member, his duties only involved helping to prepare the ceremonies. This is different from a bissu leader. The bissu leader has the power to organize his subordinate members.

This power factor is often the target of people who are ambitious to occupy the position of leader. With the power they have, a leader gets the honor and 
money. Socrates (in Losco, 2005) expressed his views on the ideal leader. "Good people will not want to rule for money or honor because they do not want to openly determine wages to rule and are called working for money. Also do not want to secretly reap the benefits when governing and referred to as thieves. "According to Fransiskhi (2015) there are seven main characters of an ideal leader, that is intelligent, initiative, responsible, trustworthiness, honesty, willingness to sacrifice, loved by and love his group. In general, good leaders embody the consciousness to serve sincerely.

Saidi, on the other hand, is seen by other bissu members as having experienced a divine miracle (Pamusse dewata) so no one protests when he is chosen as Puang Malolo (vice chair) to replace the Puang Malolo Ma'rang who had already become a leader. At that time, Saidi was only a week into becoming an official bissu. Shortly after Saidi was chosen to be Puang Malolo, Puang Matoa Saena fell ill. Saidi remembered when he was trained in silat under his guidance (p.205). Puang Matoa Saena stood as a symbol of honor for the calabai. He treated some sick people, and he saved many lives of the poor. Before his death, Puang Matoa Saena asked all the bissus to gather. He advised that the bissu be as a guardian of custom (p. 207). Therefore, bissus do not damage the good name that has lasted for centuries.

After Saidi was appointed to the role of Puang Malolo, he received the chance to perform I la Galigo (Bugis traditional poetry) in several cities outside the community. All this was due to a foreign researcher who was interested in the phenomena of the bissu community and Bugis's tribal culture (p.336). Saidi was the chosen personnel because of his mastery on the Lontarak alphabets. Consequently, Saidi's roles became split. He rarely led the ordinary ceremonial activities for which he was responsible, having left the Arajang Ball (center of bissu activity) and moved abroad. The situation naturally resulted in a social problem involving jealousy among the members of bissu community. As a leader, Saidi was expected to serve the interests of bissu community and Bugis society in general, thus his departure caused great consternation.

Puang Saidi's position and power caused a dilemma. On the one hand, Saidi received respect as a bissu. His status was further raised by his appointment to the role of the vice-chair. On the other hand, he followed his desire to promote the Bugis culture to the world outside, causing him to neglect his official tribal duties. Saidi expressed regret that he could not physically perform both roles at once. His physical self was required to be present at the regular ritual ceremonies, while at the same time was also required overseas as a representative of his tribal culture.

Not long after Puang Saidi's departure, Puang Matoa Ma'rang (the leader of bissu community) fell ill and died. Senior bissu, Puang Nani was angered knowing of Saidi's absence as the official Puang Malolo. The body of the bissu leader could not be buried before they appointed a new leader there. Finally, because of Puang Nani's insistence and support of the other bissu, Puang Nani was chosen to replace the position of the dead leader Puang Matoa Ma'rang. This event in fact broke with tradition.

The violation of the centuries-old tradition led to a catastrophe, in which many people died. At that moment the bissu begged Puang Saidi to agree to becoming a leader. Puang Nani, however, refused to step down. Saidi was portrayed as having no ambition to become a leader. For him, being a bissu was instead regarded as a great gift. Since that time, he received respect from the people. Therefore, he left the decision to the community. However, the will of the gods said otherwise. Through a series of magical events (beyond logic) experienced by Saidi, he was finally elected to the leader of the bissu. Anderson (1972) also explained that the existence of magical powers in an Indonesian cultural context can also be seen as signifier of someone who is worthy to stand in the position of being leader.

Saidi's achievement of becoming the leader evoked compassion, given that it was achieved through a long and painful journey. This novel concludes with an inner statement from Saidi: "I am calabai, I am a bissu. Today I am Puang Matoa” (p.380). This statement implies even though he is a calabai (transvestite), now he is honored for being a member of the bissu community. The honor was more complete with the appointment of Saidi to the position of the leader of the bissu. Heavy duty awaited the bissu leader, and Saidi was acutely aware of this burden.

\section{Dissemination of Meaning}

The last stage of deconstruction analysis is disseminating meaning, since meaning is also constructed. A signifier may refer to a number of different references, giving birth to many meanings. Derrida wants to emphasize the dissemination of meaning. Dissemination means to negate certain fixed meanings (Haryatmoko, 2015: 100). Finally, it is the 
context that will limit the reference. The expression of the text's center refers to the opposition of opposition $><$ comfort. Oppression is a marker. Oppression cannot be passed through the category of grief $><$ happiness. For example, when he became a leader, Saidi was oppressed by a dilemma, between desire and responsibility.

Oppression can also refer to situations or feelings of disrespect by others. This was experienced by Saidi when he was not a member of the bissu community. Before being appointed to the role of bissu, as a transvestite, Saidi was seen as a deviant person. The key word in this instance is respect. A person who is not respected, is considered to have no identity. A person who has no identity, will suffer in his life. Another signifier is that the concept of 'deviant' is not negative in referents, but rather, deviance is explained in terms of destiny, and a 'divine will.' In this context, deviance cannot be said to be completely aberrant. The text highlights that the definition of 'deviant' which is commonly used in society to describe the identity of transvestite needs to be revised.

\section{CONCLUSION}

Based on the Derrida deconstruction of the novel Calabai, several conclusions can be reached. First, this analysis succeeds in uncovering the center of the text, namely the problem of oppression. Oppression in the novel constructs its truth system and its own meaning. Saidi was oppressed by his father, his friends, the preachers, and the surrounding community. Saidi's tortures caused him to be a transvestite. This oppression is justified by the general view within his community that transvestites are non-human beings that are considered perverted or deviant, i.e. having a male body, but female behavior.

Second, when Saidi entered the bissu community, Saidi experienced the honor of being human. This became the turning point in which the metaphysical hierarchy was reversed for Saidi. Being regarded as a human being and receiving respect from another human being became a form of recognition of his identity or existence. This forms the essence of humanism. The novel illustrates that respect does not only derive from living by adherence to social norms and living life like most people. In the case of Saidi, joining a spiritual community with its own traditional cultural context within a broader community raised his status. Ultimately, he achieved respect through recognition of his ability in the form of intelligence and supernatural powers. This was particularly evident in the election of Saidi as the leader (Puang Matoa).

The issue of discrimination formed the initial source of textual tension when introducing Saidi's journey toward becoming leader. Actually, the author ultimately emphasized the transformational effects of Saidi's entrance into the bissu community. He received respect as a human being. A person who is not respected by others is considered to have no identity. Through the method of deconstruction, the ideology behind the text can be dismantled, that is from gender identity oppression to the power reversal.

Third, overall, Derrida's concept of the binary that was not fully compatible with one of the poles of the binary opposition (supplementary) found in this text. For example, oppression $><$ comfort. The oppressed figure of Saidi did not contrast completely with comfort. Oppressed here meant the same as depressed (depressed $><$ liberated). This shows the limitations of language in expressing thoughts and feelings.

\section{ACKNOWLEDGEMENT}

I want to thank to Gabriel Fajar Sasmita (University of Sanata Dharma Yogyakarta) who kindly edited this paper.

\section{REFERENCES}

Abidin, Z. (2014). Filsafat Manusia Memahami Manusia melalui Filsafat. VII. Bandung: PT Remaja Rosdakarya.

Al-Bayqunie, P. (2016). Calabai. Jakarta: Javanica.

Anderson, B. R.O'G. (1972). "The Idea of Power in Javanese Culture.” In Holt C., et al., ed. Culture and Politics in Indonesia. Ithaca, New York: Cornell University Press. h. 1-69.

Chou, J. (2014). Transgender Penyimpangan Gen atau Perilaku. Retrieved on 26 Agustus 2017, from http://www.kompasiana.com/juliechou/ transgender-penyimpangan-gen-atau-perilaku.

Denny J.A. (2014). Menjadi Indonesia Tanpa Diskriminasi. Jakarta: Inspirasi. CO.

Dwijoseputro (1982) Dasar-Dasar Mikrobiologi. Jakarta: Djambatan.

Eagleton, Terry. (1991). Ideology: An Intoduction. New York, London: Verso.

Faidah, Mutimmatul dan Husni Abdullah. (2013). "Religiusitas dan Konsep Diri Kaum Waria." Jurnal Studi Gender Indonesia, 4(1). 
Foucault, M. (1977). Discipline and Punish: The Birth of Prison. Harmondsworth: Penguin Books.

Fransiskhi, E. (2015). Ciri-ciri Pemimpin yang Ideal dan Tidak Ideal. Retrieved on 25 Agustus 2017, from https://id.linkedin.com/pulse/ciri-ciri-karakterpemimpin-yang-ideal-dan-tidak-eddy-fransiskhi.

Hamid, N. (2011). Perlindungan Hukum Bagi Waria dari Tindakan kekerasan dalam Rumah Tangga: Perspektif Hukum Islam (Studi Kasus Waria Kota Malang). Skripsi. UIN Malang.

Haryatmoko (2017). "Dekonstruksi Derrida." Paper dalam Pelatihan Kritik Sastra di Universitas Sanata Darma, Yogyakarta.

Haryatmoko (2015). Membongkar Rezim Kepastian. Pemikiran Kritis PostStrukturalis. Yogyakarta: Penerbit Boekoe Tjap Petroek.

Komnas Temukan Dugaan Pelanggaran HAM Kasus Papua di Yogya (2016). Retrieved on 27 Agustus 2017, from http://www.bbc.com/indonesia/ berita_indonesia/2016/07/160720_indonesia_ komnas papua.

Losco, J. dan Williams, L. (2005). Political Theory: Kajian Klasik dan Kontemporer. Jakarta: Rajawali Pers.

Makkulau, M. F. W. (2008). Manusia Bissu. Makassar: Pustaka Refleksi.

Muftisany, H. (1970). Hukum Berperilaku Menyerupai Lawan Jenis. Retrieved on 25 Agustus 2017, from http://www.republika.co.id/berita/koran/dialogjumat/16/02/26/o357g813-hukum-berperilakumenyerupai-lawan-jenis.
Oetomo, D. (2001). Memberi Suara Pada yang Bisu. Yogyakarta: Pustaka Marwa Yogyakarta.

Rudi (2016). The Depiction of Homosexuality in American Movies. Humaniora, 28(1), 59-68.

Sebelas Kasus Pelanggaran Hak Kebebasan Beragama di Indonesia. Retrieved on 27 Agustus 2017. from http://informasidalamnegeri.blogspot. co.id/2016/07/11-kasus-pelanggaran-hakkebebasan.html.

Stocker, B. (2006). Routledge Philosophy Guidebook to Derrida on Deconstruction. New York: Routledge.

Sugiharto, B. (2000). Penjara Jiwa, Mesin Hasrat: Tubuh Sepanjang Budaya. Kalam, 15, 26-42.

Triadnyani, I G. A. A. M. (2014). Fenomena Rangda dan Pemaknaannya: Kajian Hermeneutika Ricoeur dalam Teks Calon Arang dan Novel Janda dari Jirah. Unpublish Dissertation. Universitas Indonesia, Depok.

Ubaidullah A.R. (2012). Humanisme: Manusia sebagai Pusat. Retrieved on 25 Agustus 2017, from http:// capiyubaid.blogspot.co.id/2012/11/humanismemanusia-sebagai-pusat.html.

Yuliani, S. (2012). Diskriminasi Waria dalam Memperoleh Pelayanan Publik Dasar: Tinjauan dari Perspektif Human Governance. Retrieved on 25 Agustus 2017, from http://sriyuliani.staff.fisip. uns.ac.id/wp-content/uploads/sites/10/2012/06/ DISKRIMINASI-WARIA-PROSIDING-ASPA1. pdf. 